\title{
MENINGKATKAN HASIL BELAJAR SISWA PADA POKOK BAHASAN MENULIS PUISI DENGAN MENGGUNAKAN MEDIA VISUAL TIGA DIMENSI (3D) KELAS V SD
}

\author{
Nancy Angelia Purba ${ }^{1}$, Veria Tika Sihombing ${ }^{2}$ \\ ${ }^{1,2}$ Universitas HKBP Nommensen Pematangsiantar, Indonesia. \\ Email: nancypurba27@gmail.com ${ }^{1}$, veriatikasihombing@ gmail.com ${ }^{2}$
}

\begin{abstract}
This research is a classroom action research on the subject of writing poetry. The data collection tools used in this study were observation sheets and tests. Based on the results of the first cycle of learning, the results of the implementation of learning activities for teachers were $59 \%$ in the sufficient category and the implementation of learning activities for students scored 70 in the good category, the mastery of individual student learning was 12 students, while the mastery of learning classically was obtained 66.67 with an average of 74.16. Cycle II learning outcomes with improvements in the implementation of learning on teacher activities obtained $80 \%$ with good categories and the results of the implementation of learning on student activities obtained 84 with good categories, individual learning completeness is 16 students, while classical completeness is 88.8 and the average value an average of 83.88 .
\end{abstract}

Keywords: learning outcomes, three-dimensional (3D) visual media

\begin{abstract}
ABSTRAK
Penelitian ini merupakan penelitian tindakan kelas pada pokok bahasan menulis puisi. Alat pengumpul data yang digunakan dalam penelitian ini adalah lembar observasi dan tes. Berdasarkan hasil pembelajaran Siklus I diperoleh hasil pelaksanaan pembelajaran aktivitas guru 59\% dengan kategori cukup dan pelaksanaan pembelajaran aktivitas siswa mendapat nilai 70 dengan kategori baik, ketuntasan belajar siswa secara individu adalah 12 siswa, sedangkan ketuntasan belajar secara klasikal diperoleh 66,67 dengan rata-rata sebesar 74,16. Hasil belajar Siklus II dengan perbaikan pelaksaaan pembelajaran pada aktivitas guru diperoleh $80 \%$ dengan kategori baik dan hasil pelaksanaan pembelajaran pada aktivitas siswa diperoleh 84 dengan kategori baik, ketuntasan belajar secara individu yaitu 16 siswa, sedangkan ketuntasan secara klasikal adalah 88,8 dan nilai rata-rata sebesar 83,88.
\end{abstract}

Kata Kunci: hasil belajar, media visual tiga dimensi (3D)

\section{PENDAHULUAN}

Pendidikan merupakan proses pemberdayaan yang diharapkan dapat memberdayakan siswa menjadi manusia yang cerdas, beretika dan berkepribadian yang dapat diandalkan sesuai dengan sistem Pendidikan Nasional Nomor 20 tahun 2003. Salah satu proses pembelajaran yang diselenggarakan di sekolah yaitu untuk mengarahkan perubahan pada diri siswa secara terencana baik dalam aspek pengetahuan, keterampilan dan sikap. Proses pendidikan di sekolah, kegiatan belajar adalah kegiatan yang paling pokok. Kegiatan belajar yang dilakukan siswa adalah untuk kebutuhan dirinya seperti pelajaran bahasa Indonesia. Bahasa Indonesia menjadi salah satu pembelajaran yang wajib dilaksanakan pada pendidikan di Indonesia yang harus dimiliki siswa yaitu keterampilan mendengarkan, berbicara, membaca dan menulis (Dalman, 2012:3). Hal ini senada dengan Tarigan (2008:1) kemampuan menulis bisa dimiliki dan dipahami melalui praktik dan latihan. Melalui proses kreatif, kemampuan siswa dalam mata pelajaran menulis bisa dikembangkan. Daya kreatif siswa diharapkan mampu meningkatkan keberanian dirinya dalam mengungkapkan idea tau gagasan yang ada dalam pikirannya.

Menulis juga merupakan cara yang baik untuk mewujudkan menjelaskan serta 
mengungkapkan ide, konsep, gagasan dan pikiran ke dalam suatu bentuk tulis (NS. Sutarno, 2008:10). Kemampuan siswa dalam menulis akan membantu seseorang untuk berpikir secara kritis karena dengan menulis seseorang akan maksimal dalam menyikapi suatu hal atau informasi terteu yang ia temukan di daerah sekitarnya. Melalui pembelajaran sastra siswa dalam hal ini menulis puisi diharapkan kemampuan berpikir kreatif menciptakan daya guna yang bermanfaat khususnya dalam tulisan. Bentuk-bentuk sastra yang diajarkan dalam pengajaran sastra di sekolah seperti cerpen, puisi maupun drama. Bentuk sastra yang diajarkan melalui puisi, siswa harus mampu mengungkapan perasaan dengan imajinatif karena puisi tidak lepas dari seni merangkai kata yang penuh makna. Pengajaran puisi di sekolah dasar perlu digalakkan sejak dini sehingga siswa mampu menulis puisi dengan menggunakan pilihan kata yang sesuai dengan beberapa tulisan. Intinya, seorang siswa sekolah dasar harus memanfaatkan berbagai hal dalam proses kreativitas menulis.

Media visual tiga dimensi (3D) merupakan salah satu media yang digunakan dan bentuknya bisa dilihat dari arah mana saja serta mempunyai dimensi panjang, lebar dan tinggi/tebal. Media visual tiga dimensi (3D) adalah media yang tidak diproyeksi serta ditampilkan secara visual tiga dimensi (3D). Kelompok media ini bisa berupa benda asli, hidup atau mati, sertabisa berupa tiruan yang mewakili benda aslinya. Ketika benda asli difungsikan untuk media pembelajaran bisa dihadirkan langsung ke dalam kelas atau siswa bisa diajak langsung ke dunia luar dimana ada benda aslinya. Apabila benda asli tidak bisa dihadirkan di dalam kelas atau siswa tidak bisa dihadapkan langsung ke tempat dimana adanya benda asli, oleh karena itu miniatur bisa mempunyai fungsi sebagai media pembelajaran yang efektif (Daryanto, 2013:29). Menurut Edgar Dale dalam Rumampuk (1988:207) menyatakan bahwa manfaat dari pengalaman siswa menghadapi benda tiruan dalam menghadapi media visual tiga dimensi (3D) yaitu siswa mendapatkan pengalaman melalui benda-benda atau kejadian-kejadian tiruan, artinya benda-benda ini mirip dengan benda aslinya, tapi ada perbedaan dari ukuran.

Selain itu, manfaat dari pengalaman siswa melalui lambang-lambang visual adalah alat komunikasi lambang visual bisa memberi pengetahuan melalui media visual tiga dimensi (3D), siswa mampu memahami apa yang sudah digambarkan melalui lambang visual.

\section{METODE PENELITIAN}

\section{Jenis Penelitian}

Jenis penelitian ini adalah Penelitian Tindakan Kelas (PTK) yang bertujuan untuk memperbaiki proses pembelajaran dalam meningkatkan hasil belajar Bahasa Indonesia siswa pada pokok bahasan menulis puisi. Penelitian ini dilakukan di kelas V SDN Negeri 091281 Batu IV pada semester genap T.P 2020/20201 Kabupaten Simalungun. Alasan peneliti memilih lokasi ini, yakni: (1) sekolah ini belum pernah dilakukan penelitian menggunakan media visual tiga dimensi (3D) pokok bahasan menulis puisi; (2) guru terbuka pada pemberian informasi baru. Subjek penelitian ini adalah siswa kelas V SDN Negeri 091281 Batu IV T.P 2020/2021 yang berjumlah 18 orang yang terdiri atas 8 laki-laki dan 10 perempuan.

Objek penelitian ini adalah meningkatkan hasil belajar siswa pada pokok bahasan menulis puisi dengan menggunakan media visual tiga dimensi di kelas $\mathrm{V}$ 091281 Batu IV T.P 2020/2021. Desain penelitian ini memiliki beberapa tahapan pelaksanaan yang dilakukan di dalam kelas, meliputi pelaksanaan PTK berupa refleksi awal dan observasi untuk mengetahui masalah yang terjadi di dalam kelas. 


\section{Prosedur Penelitian}

Penelitian ini bertujuan untuk mengetahui pelaksanaan dan hasil belajar siswa pada pokok bahasan menulis puisi dengan menggunakan media visual tiga dimensi siswa kelas V 091281 Batu IV T.P 2020/2021. Prosedur penelitian yang dilakukan dalam penelitian ini adalah melalui tahapan yang diungkapkan Suharsimi Arikunto (2014:31) yaitu perencanaan, tindakan, pengamatan, dan refleksi.

\section{Teknik Pengumpulan Data}

Alat pengumpul data yang digunakan adalah observasi dan tes. Teknik Analisis data yang digunakan dalam penelitian ini adalah analisis data tentang pelaksanaan pembelajaran dan hasil belajar siswa. Menentukan ketuntasan belajar siswa (individu) dapat dihitung dengan menggunakan rumus persamaan sebagai berikut:

Dimana :

$$
\left.\mathrm{KB}=\frac{T}{T_{t}} x 100 \% \ldots . \text { (Trianto, } 2011: 241\right)
$$

$$
\begin{array}{ll}
\mathrm{KB} & =\text { Ketuntasan belajar } \\
\mathrm{T} & =\text { Jumlah skor yang diperoleh siswa } \\
\mathrm{T}_{\mathrm{t}} & =\text { Jumlah skor total }
\end{array}
$$

Setiap siswa dikatakan tuntas belajarnya (ketuntasan individu) jika hasil belajarnya mencapai nilai Kriteria Ketuntasan Minimum (KKM) sekolah atau mendapatkan nilai 70 .

\section{HASIL PENELITIAN DAN PEMBAHASAN Siklus I}

Penelitian ini dilakukan di SDN 091281 Batu IV T.P 2020/2021 dengan jumlah siswa sebanyak 18 orang. Peneliti melaksanakan kegiatan belajar mengajar dengan berpedoman pada RPP. Sewaktu pembelajaran berlangsung, observer yaitu guru kelas V SDN 091281 Batu IV mengamati aktivitas guru dan aktivitas siswa.

Pelaksanaan penelitian siklus I dengan empat tahap yaitu Tahap perencanaan, Tahap pelaksanaan tindakan, observasi dan refleksi. Siklus I diawali dengan tahap perencanaan yang dilakukan adalah melakukan pertemuan dengan guru kelas $\mathrm{V}$, menyusun RPP, memberikan lembar observasi guru dan siswa, mempersiapkan tes, mempersiapkan media, mempersiapkan instrumen penelitian, memberitahu guru tentang kegiatan yang dilakukan sebelumnya.

Tahap pelaksanaan tindakan yang dilakukan adalah melaksanakan langkahlangkah pembelajaran, menata kelas, mengajak siswa bernyanyi, memberikan motivasi, melaksanakan pembelajaran dengan menggunakan media visual tiga dimensi. Mencatat pemahaman, memberi pertanyaan kepada siswa, melaksanakan evaluasi, mengoreksi hasil belajar siswa, tanya jawab.

Hasil observasi aktivitas guru cukup, terdapat kekurangan pada aspek mengadakan apersepsi, menyampaikan topik dan tujuan pembelajaran, menyampaikan pembelajaran dengan bahasa sederhana, melaksanakan pembelajaran secara sistematis, menyampaikan materi dengan baik, menggunakan media visual tiga dimensi untuk menjelaskan konsep menulis puisi, menjelaskan contoh soal mengenai puisi, memotivasi siswa untuk aktif bertanya, membuat kesimpulan/rangkuman, mengadakan evaluasi.

Hasil aktivitas siswa sudah terlihat baik, terdapat beberapa kekurangan pada aspek kesiapan menerima pelajaran dari guru, menyimak materi yang disampaikan oleh guru, memperhatikana contoh yang telah diperhatikan oleh guru, keinginan bertanya kepada guru, mencatat rangkuman. 
Hasil belajar siswa pada Siklus I adalah 12 siswa atau 66,67\% siswa yang belum mencapai KKM dan 6 siswa atau 33,33\% siswa yang sudah mencapai KKM. Rata-rata hasil belajar siswa adalah 74,16. Berdasarkan data belum diperoleh ketuntasan klasikal, maka dari itu masih perlu perbaikan pada siklus berikutnya.

\section{Pelaksanaan Pembelajaran Siklus I}

\section{Lembar Observasi Aktivitas Guru Siklus I}

Observasi dilakukan oleh observer yaitu guru kelas V dengan tujuan penerapan pembelajaran telah sesuai dengan skenario yang direncanakan, mulai dari awal pelaksanaan tindakan sampai berakhirnya tindakan pada pokok bahasan menulis puisi dengan menggunakan media visual tiga dimensi. Hasil yang diperoleh dengan menggunakan rumus

Dengan rumus :

$$
\begin{aligned}
& \mathrm{HP}=\frac{\text { jumlah hasil observasi }}{\text { jumlah butir pengamatan. }} \\
& \mathrm{HP}=\frac{590}{10}=59 \% \text { (cukup) }
\end{aligned}
$$

Berdasarkan data yang ada maka dapat dijelaskan aktivitas mengajar guru pada pembelajaran menulis puisi setelah menggunakan media visual tiga dimensi kelas $\mathrm{V}$ SDN 091281 Batu IV T.P 2020/2021 masih dalam kategori cukup yaitu dengan jumlah 590 dengan persentase hasil 59\%, itu artinya pembelajaran belum mencapai kriteria pelaksanaan pembelajaran yang baik.

\section{Hasil Observasi Aktivitas Siswa Siklus I}

Observasi yang dilakukan oleh guru kelas juga untuk mengamati pelaksanaan aktivitas siswa mulai dari awal pelaksanaan sampai dengan berakhirnya pembelajaran pada pokok bahasan menulis puisi dengan menggunakan media visual tiga dimensi siswa kelas V SDN 091281 Batu IV T.P 2020/2021. Hasil yang diperoleh dengan menggunakan rumus:

$$
\begin{aligned}
\text { Nilai Siswa } & =\frac{\text { skor yang diperoleh }}{\text { jumlah skor maksimum. }} \times 100 \\
& =\frac{35}{50} \times 100 \\
& =70 \text { (Baik) }
\end{aligned}
$$

Berdasarkan data yang ada dapat dijelaskan bahwa aktivitas siswa pada pokok bahasan menulis puisi dengan Menggunakan media visual tiga dimensi Siswa Kelas V SDN 091281 Batu IV T.P 2020/2021 sudah tergolong dalam kategori baik yaitu 70, artinya pembelajaran sudah mencapai kriteria pelaksanaan pembelajaran yang baik.

\section{Hasil Ketuntasan Siswa Siklus I}

Berdasarkan hasil belajar yang diperoleh pada Siklus I yang telah dilaksanakan, maka di peroleh ketuntasan hasil belajar secara individu, ketuntasan secara klasikal dan rata-rata sebagai berikut:

\section{Ketuntasan Secara Individu Siklus I}

Hasil pelaksanaan tindakan siklus I, peserta didik diberi soal tes berupa essay (tes tertulis) untuk mengetahui kemampuan dan tingkat ketuntasan peserta didik terhadap materi yang telah diajarkan. Tingkat ketuntasan individu peserta didik kelas V SDN 091281 Batu IV pada pokok bahasan menulis puisi setelah menggunakan Media visual tiga dimensi di Siklus I dapat dilihat pada gambar diagram 4.1 di bawah ini : 


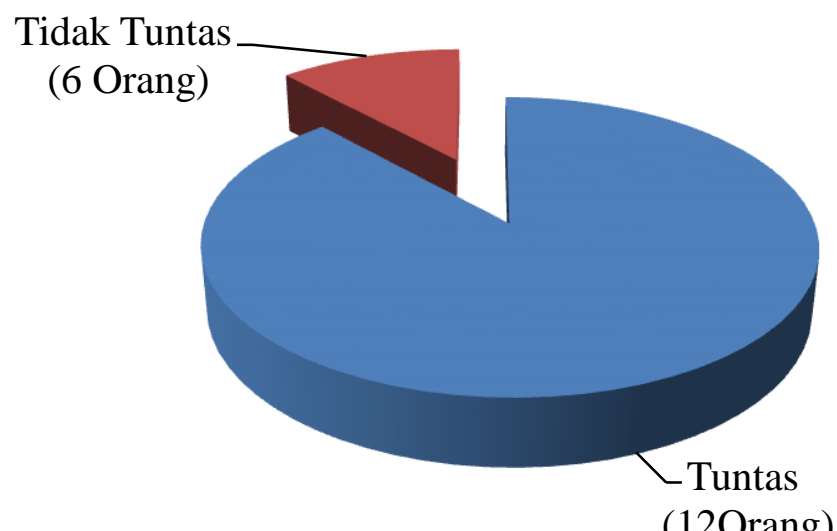

\section{Gambar 1 Diagram Ketuntasan Belajar Siswa Secara Individu Siklus I}

\section{Ketuntasan Secara Klasikal Siklus I}

Ketuntasan secara klasikal pada siklus I dapat dilihat dari diagram di bawah ini.

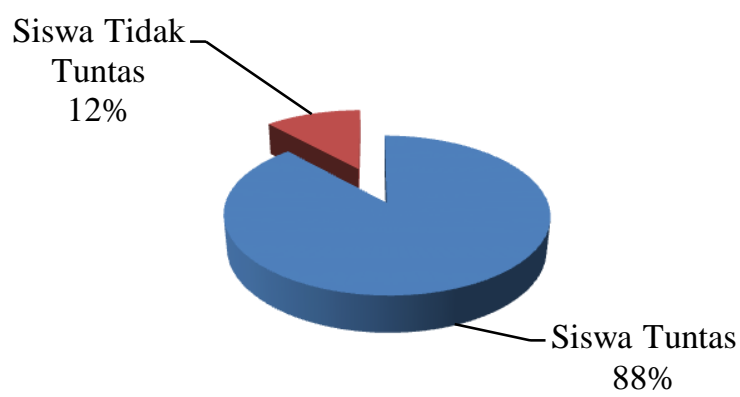

\section{Gambar 2 Diagram Ketuntasan Hasil belajar Siswa Secara Klasikal Siklus I}

\section{Refleksi Siklus I}

Berdasarkan analisis data pada siklus I dapat diketahui bahwa pelaksanaan pembelajaran sudah mencapai kategori baik. Lembar observasi dapat diketahui bawah presentasi pencapaian nilai pelaksanaan aktivitas guru masih mencapai nilai 59\%. Begitu pula dengan pencapaian nilai pelaksanaan aktivitas siswa sudah mencapai nilai 70. Artinya pelaksanaan aktivitas guru masih dalam kategori cukup dan pelaksanaan aktivitas siswa sudah dalam kategori baik. Penggunaan visual tiga dimensi dapat memotivasi siswa untuk lebih giat dan senang dalam belajar.

Berdasarkan lembar observasi aktivitas guru terdapat komponen penilaian kategori cukup dan memerlukan perbaikan seperti: (1) membentuk kelompok sesuai dengan kemampuan yang dimiliki siswa; (2) mengadakan apersepsi seperti bernyayi, memberi motivasi dan semangat agar siswa lebih semangat belajar; (3) menyampaikan materi dengan baik; (4) melaksanakan pembelajaran sesuai dengan RPP.

Berdasarkan lembar aktivitas siswa, beberapa komponen penilaian sudah baik, tetapi ada perbaikan seperti: (1) mengajak siswa menerima pelajaran dari guru; (2) memberikan contoh mengenai pengukuran waktu; (3) meningkatkan motivasi siswa 
untuk bertanya.

Berdasarkan analisis data siklus I dapat diketahui bahwa hasil belajar siswa, diketahui sebanyak 12 orang siswa $(66,67 \%)$ yang tuntas belajar dan sebanyak 6 orang siswa $(33,33 \%)$ tidak tuntas belajar. Artinya hasil belajar siswa belum maksimal dan belum tuntas secara klasikal, untuk itu diperlukan tindakan perbaikan pada siklus berikutnya.

Berdasarkan data tersebut di atas maka perlu dilakukan perbaikan pelaksanaan pembelajaran untuk mengatasi kesulitan-kesulitan siswa yang tidak tuntas pada pokok bahasan menulis puisi dengan menggunakan media visual tiga dimensi di kelas $\mathrm{V}$ SDN 091281 Batu IV T.P 2020/2021. Mendapatkan hasil maksimal hal yang perlu dilakukan sebagai refleksi dan pedoman tindakan pada siklus berikutnya karena pada siklus I pelaksanaan pembelajaran sudah berkategori baik dan hasil belajar belum tuntas secara klasikal $\geq 85 \%$ maka perlu dilakukan perbaikan pada siklus selanjutnya yaitu siklus II.

\section{Siklus II}

Dengan melakukan perbaikan dalam proses pembelajaran berdasarkan siklus I yaitu pada aktivitas guru yaitu pada aspek: mengadakan apersepsi, menyampaikan topik dan tujuan pembelajaran, menyampaikan pembelajaran dengan bahasa sederhana, melaksanakan pembelajaran secara sistematis, menyampaikan materi dengan baik, menggunakan media visual tiga dimensi untuk menjelaskan konsep menulis puisi, menjelaskan contoh soal mengenai menulis puisi, memotivasi siswa untuk aktif bertanya, membuat kesimpulan/rangkuman, mengadakan evaluasi.

Perbaikan pada aktivitas siswa yaitu pada aspek kesiapan menerima pelajaran dari guru, menyimak materi yang disampaikan oleh guru, memperhatikan contoh yang telah diperhatikan oleh guru, keinginan bertanya kepada guru, mencatat rangkuman.

Siklus II dilaksanakan sama seperti Siklus I.

Hasil belajar siswa pada Siklus II adalah 16 siswa atau 88,8\% siswa yang sudah mencapai KKM dan 2 siswa atau 11,2\% siswa yang belum mencapai KKM. Rata-rata hasil belajar siswa adalah $83,88 \%$. Pelaksanaan pembelajaran Siklus II meningkat dari semua aspek baik aktivitas guru dan aktivitas siswa dan hasil belajar sehingga tidak perlu dilakukan ke siklus berikutnya.

\section{Hasil Observasi Aktivitas Guru Siklus II}

Saat peneliti melakukan tindakan perbaikan di siklus II, peneliti juga melakukan kerja sama dengan guru kelas $\mathrm{V}$ untuk mengamati segala kegiatan yang dilakukan dalam proses pembelajaran sehingga diperoleh gambaran dari kegiatan pembelajaran yang dilaksanakan guru praktikan di kelas

Berdasarkan data dapat dijelaskan bahwa aktivitas mengajar guru pada tindakan perbaikan di siklus II yang telah dilaksanakan pada pokok bahasan menulis puisi dengan menggunakan media visual tiga dimensi siswa kelas V SDN 091281 Batu IV T.P 2020/2021 sudah mencapai kategori baik yaitu dengan jumlah 800 atau $80 \%$.

\section{Lembar Observasi Aktivitas Siswa Siklus II}

Observasi yang dilakukan oleh guru kelas pada siklus II juga untuk mengamati pelaksanaan aktivitas siswa mulai dari awal sampai dengan berakhirnya pelaksanaan tindakan perbaikan dengan menggunakan media visual tiga dimensi pada mata pelajaran Bahasa Indonesia pokok bahasan menulis puisi.

Dengan rumus : 
Nilai Siswa $=\frac{\text { skor yang diperoleh }}{\text { jumlah skor maksimum. }} x 100$

$$
=\frac{42}{50} \times 100=84 \text { (Baik) }
$$

Berdasarkan tabel 3.5 dapat dijelaskan bahwa aktivitas belajar siswa pada siklus II memperoleh nilai 84, itu artinya pembelajaran sudah mencapai kategori baik.

\section{Hasil Ketuntasan Siswa Siklus II}

\section{Ketuntasan Secara Individu Siklus II}

Hasil pelaksanaan tindakan siklus II maka diperoleh ketuntasan hasil belajar siswa secara individu di kelas V SDN 091281 Batu IV T.P 2020/2021 setelah menggunakan media visual tiga dimensi pada pembelajaran bahasa Indonesia pokok bahasan menulis puisi adalah berdasarkan data yang diperoleh siswa yang tuntas belajar dari 18 siswa, 16 siswa yang tuntas secara individu, dan 2 siswa yang tidak tuntas, dapat dilihat pada gambar diagram 4.3 di bawah ini :

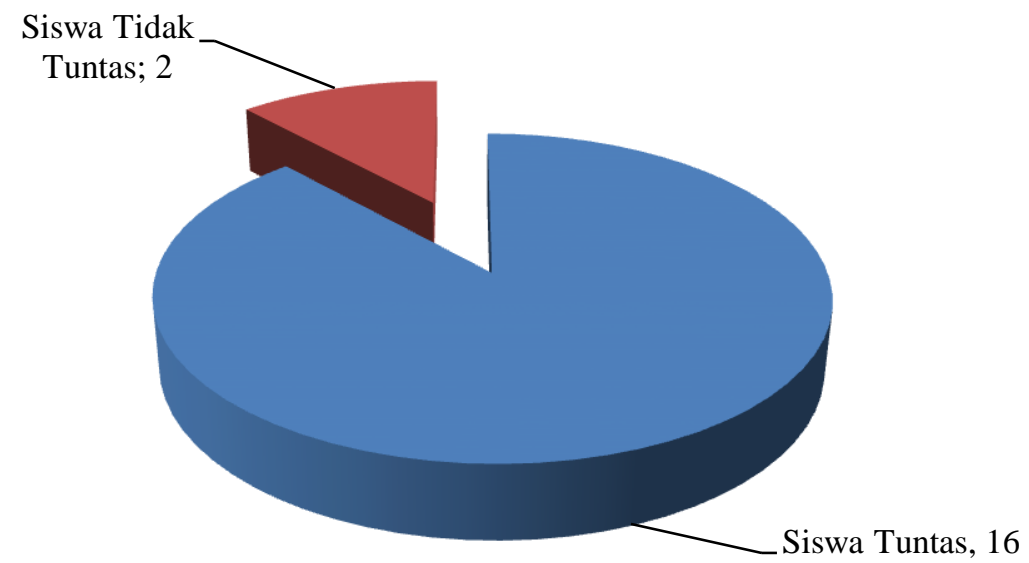

\section{Gambar 3 Diagram Ketuntasan Hasil Belajar Siswa Secara Individu Siklus II}

\section{1) Ketuntasan Secara Klasikal Siklus II}

Hasil yang diperoleh, siswa sudah dapat dikatakan tuntas secara klasikal karena suatu kelas dikatakan tuntas belajarnya di dalam suatu kelas tersebut $\geq 85 \%$ siswa yang telah tuntas belajarnya. Berikut akan digambarkan ketuntasan hasil belajar siswa secara klasikal pada siklus II dalam diagram.

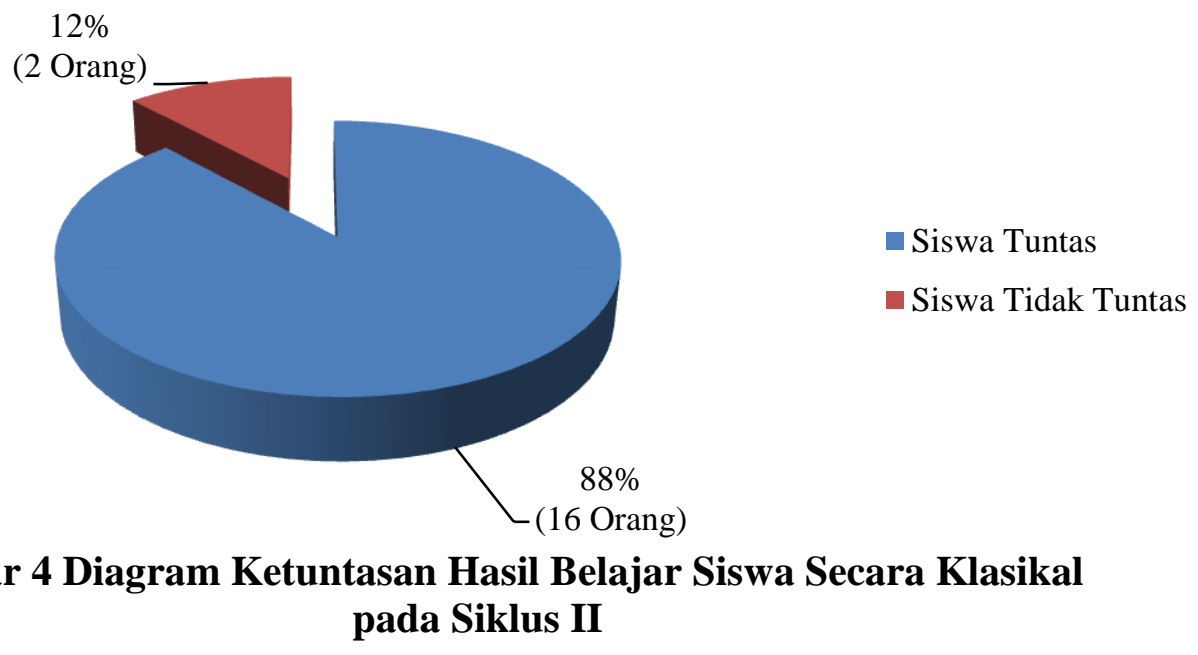




\section{Rata-Rata Hasil Belajar Siklus II \\ Refleksi Siklus II}

Berdasarkan analisis data pada siklus II dapat diketahui bahwa pelaksanaan pembelajaran sudah maksimal dan mencapai kategori baik. Lembar observasi dapat diketahui bahwa presentasi pencapaian nilai pelaksanaan aktivitas guru sudah mencapai nilai $80 \%$. Begitu pula dengan pencapaian nilai pelaksanaan aktivitas siswa sudah mencapai nilai $84 \%$.

Hasil belajar siswa, diketahui sebanyak 18 siswa atatu 88,88\% mendapat nilai tuntas. Itu artinya hasil belajar siswa sudah maksimal dan tuntas secara klasikal, dengan rata-rata nilai siswa di atas KKM yaitu 83,88. Sesuai dengan tujuan penelitian bahwa pelaksanaan pembelajaran pada pokok bahasan menulis puisi dengan menggunakan media visual tiga dimensi dapat meningkatkan hasil belajar siswa kelas V SDN 091281 Batu IV T.P 2020/2021, dengan demikian tidak diperlukan lagi tindakan perbaikan pada siklus berikutnya.

\section{Pembahasan}

Hasil pelaksanaan perbaikan pembelajaran yang dilaksanakan pada pokok bahasan menulis puisi dengan menggunakan visual tiga dimenis siswa kelas V SDN 091281 Batu IV T.P 2020/2021 dengan subjek penelitian sebanyak 18 orang siswa diperoleh :

\section{Hasil Observasi Aktivitas Guru Siklus I dan Siklus I}

Berdasarkan hasil pelaksanaan pembelajaran observasi aktivitas guru pada siklus I dan siklus II diperoleh pelaksanan pembelajar siklus I dengan persentase $64,7 \%$ berkategori cukup dan pada siklus II diperoleh persentase $80 \%$ berkategori baik pada poko bahasan menulis puisi dengan menggunakan media visual tiga dimensi siswa kelas V SDN 091281 Batu IV T.P 2020/2021.

\section{Penilaian Aktivitas Guru}

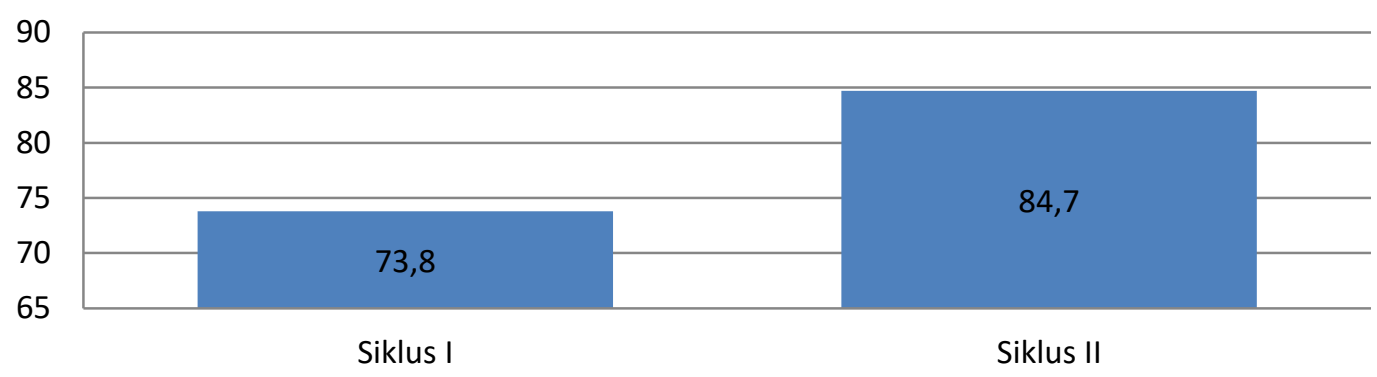

\section{Gambar 5 Diagram Hasil Observasi Aktivitas Guru Siklus I dan II}

\section{Hasil Observasi Aktivitas Siswa}

Berdasarkan hasil pelaksanaan pembelajaran observasi aktivitas siswa pada siklus I dan siklus II diperoleh pelaksanan pembelajaran siklus I mencapai nilai 70 dengan kategori baik, siklus II mencapai nilai 84 berkategori baik pada pokok bahasan menulis puisi dengan menggunakan media visual tiga dimensi siswa kelas V SDN 091281 Batu IV T.P 2020/2021. Berikut adalah tabel hasil observasi aktivitas guru di bawah ini:

Peningkatan aktivitas siswa dari siklus I ke siklus II dapat dilihat pada diagram di bawah ini : 


\section{Penilaian Aktivitas Siswa}

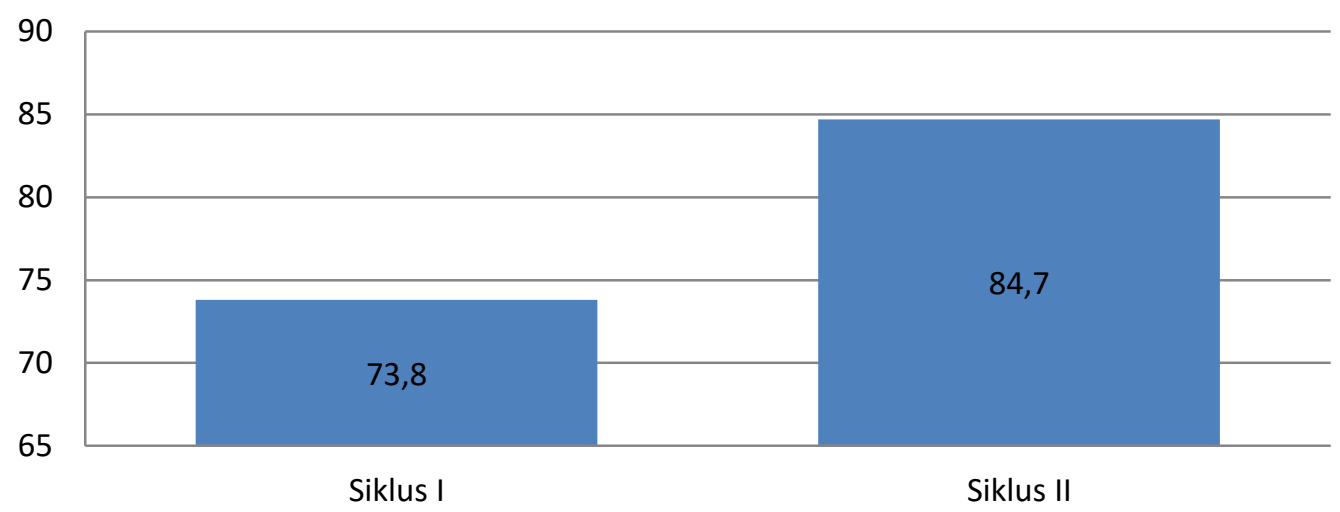

Gambar 6 Diagram Hasil Observasi Aktivitas Siswa Siklus I dan II

\section{Hasil Belajar Siswa}

\section{Ketuntasan Hasil Belajar Secara Individu}

Berdasarkan hasil tes yang diberikan kepada siswa setelah pembelajaran Siklus I dan Siklus II maka diperoleh ketuntasan hasil belajar secara individu hasil rekapitulasi ketuntasan hasil belajar secara individu dapat dilihat pada tabel berikut ini:

Tabel 1 Ketuntasan Hasil Belajar Secara Individu

\begin{tabular}{cccc}
\hline & Siklus I & Siklus II & Keterangan \\
\hline Siswa yang Tuntas & 6 & 16 & \\
\cline { 1 - 3 } Siswa yang Tidak Tuntas & 12 & 2 & \\
\hline
\end{tabular}

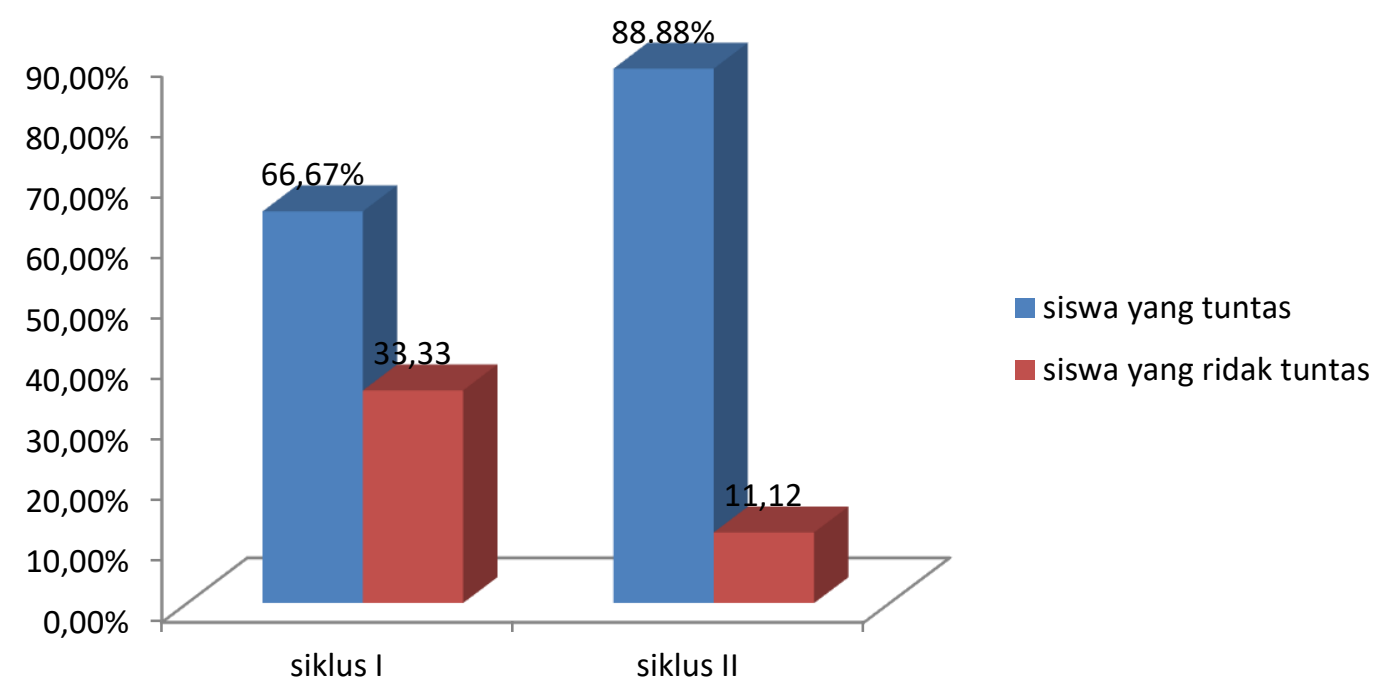

\section{Gambar 7 Diagram Ketuntasan Belajar Siswa Secara Individu Siklus I dan Siklus II}

\section{a. Ketuntasan Hasil Belajar Secara Klasikal}

Hasil belajar siswa secara individu yang diperoleh maka dapat ditentukan ketuntasan hasil belajar siswa secara klasikal dituliskan pada tabel di bawah ini: 
Tabel 2 Ketuntasan Hasil Belajar Secara Klasikal

\begin{tabular}{cccc}
\hline Keterangan & Siklus I & Siklus II & Keterangan \\
& & & \\
\hline Siswa yang Tuntas & 66,67 & 88,88 & \multirow{2}{*}{ Meningkat } \\
\hline Siswa yang Tidak Tuntas & 33,33 & 11,12 & \\
\hline
\end{tabular}

Berdasarkan Tabel diketahui bahwa ketuntasan hasil belajar secara klasikal pada Siklus I diperoleh persentase $66,67 \%$ siswa tuntas belajar dan 33,33\% siswa yang tidak tuntas belajar. ketuntasan hasil belajar secara klasikal pada Siklus II diperoleh persentase $88,88 \%$ siswa tuntas belajar dan $11,12 \%$ siswa yang tidak tuntas belajar. Berdasarkan hasil belajar tersebut ketuntasan klasikal meningkat.

\section{Rata-Rata Hasil Belajar}

Hasil belajar bahasa Indonesia siswa siklus I dan siklus II memiliki rata-rata yang berbeda, hal tersebut dikarenakan adanya perbaikan pembelajaran pada siklus II sehingga terjadi peningkatan hasil belajar siswa siklus II. Berikut ini adalah tabel ratarata hasil belajar siklus I dan siklus II.

Tabel 3 Rata-rata Hasil Belajar

\begin{tabular}{ccc}
\hline & Rata-rata & Keterangan \\
\hline Siklus I & 74,16 & Meningkat \\
Siklus II & 83,88 & \\
\hline
\end{tabular}

Siklus I nilai rata-rata hasil belajar bahasa Indonesia siswa pokok bahasan menulis puisi adalah 74,16 dengan siswa yang tuntas sebanyak 12 orang dengan persentase $66,67 \%$. Jelas terlihat bahwa pada siklus I siswa tuntas belajar secara individu, namun secara klasikal siswa belum tuntas belajar. Hal tersebut dikarenakan siswa yang tuntas belum mencapai $\geq 85 \%$ siswa yang tuntas belajar atau mendapat nilai $\geq 70$. pada siklus II nilai rata-rata hasil belajar siswa telah meningkat dengan nilai 83,88 . Siswa yang tuntas dalam pembelajaran siklus II sebanyak 16 orang dengan persentase sebesar $88,88 \%$. Pada siklus II ini siswa telah tuntas belajar secara individu dan klasikal, karena jumlah siswa yang tuntas belajar bahasa Indonesia pokok bahasan menulis puisi $\geq 85 \%$. Peningkatan nilai rata-rata dan ketuntasan hasil belajar matematika siswa antara siklus I dan siklus II yaitu 22\%. Disimpulkan bahwa pembelajaran dengan menggunakan media visual tiga dimensi pada siklus II telah menunjukkan peningkatan sehingga hasil belajar siswa pada siklus II juga meningkat.

\section{Persentase Peningkatan Hasil Belajar Siswa}

Persentase Peningkatan Hasil Belajar Siswa:

$$
\begin{aligned}
& \frac{\text { rata }- \text { rata siklus } I I-\text { rata }- \text { rata siklus } I}{\text { rata }- \text { rata siklus } I} \\
& =\frac{83,88-74,16}{74,16} \times 100 \% \\
& =\frac{9,72}{74,16} \times 100 \%
\end{aligned}
$$




$$
=13,10 \%
$$

Peningkatan nilai rata-rata siswa yang diperoleh adalah $13.10 \%$.

Tabel 4 Rekapitulasi Data Hasil penelitian Siklus I dan II

\begin{tabular}{|c|c|c|}
\hline Data & Siklus I & Siklus II \\
\hline $\begin{array}{l}\text { Pelaksanaan Pembelajaran : } \\
\text { a. Aktivitas Guru }\end{array}$ & $\frac{590}{10}=59 \%$ & $\frac{800}{10}=80 \%$ \\
\hline b. Aktivitas Siswa & $\frac{35}{50} \times 100=70$ & $\frac{42}{50} \times 100=84$ \\
\hline $\begin{array}{l}\text { Hasil Belajar: } \\
\text { a. Tuntas Individu }\end{array}$ & 12 & 16 \\
\hline b. Tuntas Klasikal & $\frac{12}{18} \times 100$ & $\frac{16}{18} \times 100=$ \\
\hline c. Rata-rata & $\begin{array}{l}=66,67 \% \\
74,16\end{array}$ & $\begin{array}{l}=88,8 \% \\
83,88\end{array}$ \\
\hline
\end{tabular}

Berdasarkan hasil penelitian yang telah dilakukan maka hipotesis tindakan yang diajukan dalam penelitian pada pokok bahasan menulis puisi dengan menggunakan media visual tiga dimensi siswa kelas V SDN 091281 Batu IV T.P 2020/2021 dapat diterima.

\section{PENUTUP}

Berdasarkan hasil penelitian dan pembahasan yang dilakukan di kelas V SDN 091281 Batu IV T.P 2020/2021 dapat disimpulkan: Pelaksanaan pembelajaran pada pokok bahasan menulis puisi dengan menggunakan media visual tiga dimensi siswa kelas V SDN 091281 Batu IV T.P 2020/2021 dengan rincian observasi aktivitas guru dan observasi aktivitas siswa sudah mencapai kategori baik. Ketuntasan hasil belajar pada pokok bahasan menulis puisi dengan menggunakan media visual tiga dimensi siswa kelas V SDN 091281 Batu IV T.P 2020/2021 sudah tuntas secara klasikal. Hasil belajar siswa pada pokok bahasan menulis puisi dengan menggunakan visual tiga dimensi siswa kelas V SDN 091281 Batu IV T.P 2020/2021 telah meningkat.

\section{DAFTAR PUSTAKA}

Dalman. 2012. Keterampilan Menulis. Jakarta: Rajawali Pers.

Daryanto. 2013. Media Pembelajaran (Peranannya Sangat Penting Dalam Mencapai Tujuan Pembelajaran). Yogyakarta: Gava Media

NS, Sutamo. 2008. Menulis Yang Efektif. Jakarta: Sagung Seto

Rumampuk, D.B. 1998. Media Instruksional IPS. Jakarta: Departemen

Pendidikan dan Kebudayaan

Sandewita, N. 2014. Media Pembelajaran 3Dimensi. (online).

Tersedia: http://www.vh asande.blogspot.com/2014/04/media-pembelajaran-3dimensi.html?m=1

Tarigan, H.G. 2008. Menulis sebagai suatu keterampilan berbahasa. Bandung: Angkasa

Purba, Nancy Angelia. 2016. Penerapan Teknik Rekayasa Teks dengan 
Media Komputer dalam Meningkatkan Kemampuan Menulis Puisi.

Volume 6 No. 3 Desember 2016

Arikunto, Suharsimi. 2014. Prosedur Penelitian Suatu Pendekatan Praktik. Jakarta: Rineka Cipta.

Trianto. 2011. Mendesain Model Pembelaaran Inovatif-Progresi. Jakarta: Prenada Media Group. 